on the roadside near the Sheepstor Dam. The porosity of the growan affords ample storage for rainfall, which in Devon is high, ranging up to more than 80 inches per annum. The monthly distribution is remarkably regular, when long periods are averaged, but wholly irregular in any one year. Mr. Worth went on to analyse the run-off resulting from rainfall and found that there is a drought regime for every stream, and that following any day in which there has been no actual flood, it is possible from the ascertained flow on that day accurately to predict the flow of the stream for the next 24 hours, in the absence of rain. Instances were given of several notable floods and their havoc.

\section{Protection of Underground Water Supplies}

THE second paper, on "The Protection of Underground Sources of Water Supply", by Mr. Edgar Morton, had special reference to the Town and Country Planning Acts, and was directed to two aspects of protection, namely, protection of an existing source of public supply against exploitation for industrial purposes, and, secondly, protection against the possibility of pollution from external sources. As regards the former, pointing out that in most private Acts involving underground waterworks, there is a clause for the protection of existing sources of supply-wells, boreholes and springs-within a specified radius of the authorized works, Mr. Norton stated that within recent years there has been a tendency to extend such protection to include streams, ponds and pools, in so far as they are fed by springs which originate within the protected zone, although the user of such streams, ponds or pools may be outside the zone. A serious aspect of the inadequacy of existing legislation is that, while Parliament imposes upon the promoters seeking new sources of supply for public benefit at the least possible cost, restrictions respecting their boreholes, no reciprocal protection has until recently been given to the promoters against the exploitation of their water resources by industrial enterprise. As regards protection against pollution, various ways were enumerated by which it could be obtained in limestone and chalk areas and in sandstone areas respectively, with instances of specific cases.

\section{The Argyll National Forest Park}

Reference to the Argyll National Forest Park was made in NaTURE of October 16, 1937, p. 692 ; and now a small brochure with the title "The Argyll National Forest Park Guide" has recently been issued by the Forestry Commissioners. The Guide has been edited by Prof. John Walton, regius professor of botany in the University of Glasgow, and has a foreword by Sir Roy Robinson, chairman of the Forestry Commission. The National Park consists of large stretches of mountain and moorland lying to the west of Loch Long. It is divided into two main areas. The northern consists of Ardgartan and Ardgoil and forms a wedge of mountains between Loch Goil and Loch Long. The southern area is bounded on the east by Loch Long and Loch Goil. The two areas are built up of a group of estates, the Ardgoil
Estate having been presented to the Corporation of the City of Glasgow by Mr. Cameron Corbett, the others having been acquired by the Forestry Com. mission, which has since afforested large areas. The total area of the estates amounts to 54,000 acres about 19,000 of which are reserved for afforestation, leaving approximately 35,000 acres available for use as a National Park. At the southern end of this Park are situated Benmore House and its finely laidout gardens and shrubberies which were presented to the Forestry Commissioners by Mr. Harry G. Younger. This Park presents interests for every taste and the Guide deals with its history (Prof. J. D. Mackie), geological structure (Dr. J. G. C. Anderson), vegetation (Prof. J. Walton), forests and plantations (Mr. J. M. Murray, assistant commissioner for Scotland), and fauna (Prof. E. Hindle), all, with the exception of Mr. Murray, on the staff of the University of Glasgow.

\section{British Museum (Natural History): Acquisitions}

Amovg recent additions to the zoological collections is the skull of a swamp deer (Rucervus duvauceli) from India presented by Mr. D. H. Keelan. The specimen is remarkable for the symmetry of the antlers. A collection of mammals formed by the late Captain H. D. Hilton-Simpson has been presented by Mrs. Hilton-Simpson; included in this series is a mounted head and a skull of a race of buffalo named by the late Richard Lydekker after Captain HiltonSimpson, Syncerus caffer simpsoni. A number of mammals from Kenya Colony, including a specimen of a rare crested bush rat, Lophiomys testudo, and twenty small mammals from Sierra Leone are the gifts respectively of Colonel C. H. Stockley and Mr. R. R. Glanville. An 'ivory pearl' from the tusk of a Uganda elephant has been presented by Mr. Q. O. Grogan. This concretion is an especially large one and shaped rather like a small potato. Among recent donations received from the Rowland Ward Trustees is an African tiger cat, Felis celidogaster, mounted for the galleries, and the skull of an African dwarf buffalo. A splendid group of slender prisms of stibnite (antimony sulphide) and another specimen of baryte on stibnite from Baia Sprie, Rumania, are the most interesting of the purchases made for the Department of Mineralogy. The Geological Survey of India has presented to the same Department three samples of different grades of diamondiferous gravel from the Karnool District, Madras Presidency. Diamonds in this district are obtained from alluvial deposits and also from a conglomerate at the base of the Karnool Series among rocks of Precambrian age. These gravels have been presented in response to a request for specimens to illustrate the modes of occurrence of diamond, which is the subject of the first section of the diamond case (near entrance to the Mineral Gallery) recently rearranged

The Department of Botany has purchased about 700 drawings and some manuscript of J. J. Dillenius, the first Sherardian professor of botany at Oxford. In 1719, Dillenius published his "Catalogus Plantarum

(Continued on page 31) 
sponte circa Gissam nascentium" which gained for him a considerable reputation. The knowledge he showed of cryptogams induced William Sherard to persuade him to come to England mainly to help with the "Pinex" he had undertaken on Tournefort's advice. When Sherard died he left an endowment to found a chair of botany at Oxford stipulating that Dillenius should be its first occupant. The drawings now received cover the whole period of Dillenius's activities, and include a set of copies from published works apparently made in his student days; the coloured figures of the fungi described in the Giessen catalogue; drawings of garden plants from Giessen; those in the third edition of Ray's "Synopsis" (which Dillenius edited) and many prepared and not used; plants found on a Welsh tour in 1726 ; about 200 of plants growing in the Oxford Botanic Garden, 1744-46 ; "Junci and Gramina". Most of the material which Vines and Druce mention in "The Dillenian Herbarium" (1907) as having passed into the hands of Prof. Humphrey Sibthorp and eventually disappearing and being "no doubt irrevocably lost" has thus come to light. The drawings show that Dillenius ranks much higher as a botanical artist than was generally thought. It would be highly satisfactory if the numerous letters received by Dillenius from botanical correspondents could be similarly retrieved.

\section{Astrophysical Monographs}

A valuabLe new series of monographs on astrophysical subjects is being planned by the University of Chicago Press under the auspices of the Astrophysical Journal, the editorial board of this journal serving in a similar capacity for the new series. Each monograph aims at being an exhaustive, comprehensive summary of a limited field written by an authority on the subject, and the whole should form a growing library of great use to astronomers and advanced students. In the first monograph ("The Distribution of the Stars in Space". Sup. Roy. 8vo. Pp. xvi+124. Chicago: University of Chicago Press; London : Cambridge University Press, 1937. 11s. 6d. net), Prof. B. J. Bok deals with stellar statistics and galactic structure, dividing his subject into three sections-the methods of analysis, the data of observation, and problems of galactic structure. In the first section a fuller treatment of the earlier mathematical methods, especially those developed by Charlier and others, would have been welcomed by many if the space had been available, but the necessary condensation has not impaired either the general sequence or elarity of this very readable mathematical section. It has had also the advantage of allowing more complete and critical accounts of modern numerical methods of analysis and their application to determining the distance and absorbing power of a dark nebula. The second section gives a useful summary of the relevant data of observation, and indicates where the need for further observations arises, while the last section deals with general problems of galactic structure of a more or less controversial nature. Although his own views are freely expressed, the author succeeds in giving an impartial and stimulating account of the subject, together with some tentative conclusions suggested as working hypotheses to encourage further observational studies.

\section{History of Chemistry}

WE have received a pamphlet by Prof. E. Pietsch, editor-in-chief of Gmelins Handbuch der anorganischen Chemie, which is entitled "Sinn und Aufgabe der Geschichte der Chemie". This is published by Verlag Chemie, Berlin, price 1 mark. Prof. Pietsch shows in a very convincing way the great utility of a study of the history of chemistry in the education of young chemists. He deals with the subject in its cultural aspects and makes clear how such a study can do much to remove the dangers of over-specialization now threatening chemists in the enormous development of minute detail which is occurring in the science. He also shows that a knowledge of past problems can lead to a great economy of time and effort, since in many cases large amounts of time and trouble have been expended on matters which have been fully dealt with before but forgotten. A knowledge of the history of applied chemistry also has a distinct commercial value, examples of which are given. The text includes a very brief but surprisingly complete sketch of the history of chemistry taken as a whole, with its great periods of development. The pamphlet is characterized by a maturity and a philosophical outlook which recommend it to all thoughtful students of science; and to chemists in particular it should prove stimulating and suggestive.

\section{Midland Naturalists' Union}

REPRESENTATIVES of natural history societies in the Midlands meeting in the rooms of the Birmingham Natural History and Philosophical Society on June 18 unanimously decided to form a Midland Naturalists' Union, membership of which is open to natural history, archæological and similar societies in the counties of Monmouth, Hereford, Worcester, Warwick, Leicester, Rutland, Nottingham and Lincoln. It is intended to organize an annual congress, several field meetings and, in larger towns, a number of lectures during the winter months. A list of lecturers willing to visit societies, a panel of referees for specimens and information in the various groups of plants and animals and other branches of natural history and archæology, and a system of lantern slide exchange among members, are also being organized. It is felt that the Union will facilitate co-operative work among the societies as well as bring workers into touch with others in their own branches of the subject. Further information may be obtained from the honorary secretary, G. Brian Hindle, 55 Newhall Street, Birmingham.

\section{"Dechema"}

The annual meeting of the "Dechema" held in Berlin at the end of April was attended by about 500 people, a testimony both to the interest attached to chemical engineering subjects and to the organizing energy of its director, Dr. Bretschneider. Three reports dealt with standardization, one having relation to technical terms, another to drawings and a third to corrosion from the point of view of rendering 